\title{
MODEL IDENTIFIKASI KECANDUAN GAME MENGGUNAKAN BACKWARD CHAINING
}

\author{
Anastasya Latubessy \\ Fakultas Teknik, Program Studi Teknik Informatika \\ Universitas Muria Kudus \\ Email: anastasya.latubessy@umk.ac.id \\ Esti Wijayanti \\ Fakultas Teknik, Program Studi Teknik Informatika \\ Universitas Muria Kudus \\ Email: esti.wijayanti@umk.ac.id
}

\begin{abstract}
ABSTRAK
Game menjadi kegemaran setiap orang. Baik anak-anak maupun orang dewasa senang bermain game. Seseorang dapat terus menerus bermain game sampai melupakan waktu bahkan melupakan kondisi lingkungan disekelilingnya. Keseringan dalam bermain game dapat berdampak pada tingkat kecanduan seseorang terhadap game. Namun, tidak semua orang menyadari bahwa telah memiliki jenis perilaku kecanduan game. Oleh sebab itu, dilakukan penelitian untuk mengidentifikasi jenis perilaku kecanduan game. Jenis perilaku tersebut kemudian dimodelkan menggunakan metode backward chaining. Backward chaining merupakan salah satu metode dalam teknologi sistem pakar yang melakukan identifikasi dengan penelusuran dari gejala-gejala yang ada. Dengan dilakukannya pemodelan ini, dihasilkan sebuah model identifikasi tingkat kecanduan game berdasarkan enam jenis perilaku kecanduan game seperti Salience, Euphoria, Conflict, Tolerance, Withdrawal, Relapse and Reinstatement. Model ini dapat digunakan sebagai dasar dalam pengembangan aplikasi maupun sistem komputer untuk identifikasi tingkat kecanduan game.
\end{abstract}

Kata kunci: model, kecanduan, game, backward chaining.

\section{ABSTRACT}

Game into a craze everyone. Both children and adults love to play games. Someone can continuously play games until forget the time even forget the surrounding environmental conditions. The frequency in game play can have an impact on the level of a person addicted to the game. However, not everyone is aware that it has had the type of game addiction behavior. Therefore, this research conducted to identify the type of game addiction behavior. This type of behavior is then modeled using backward chaining. Backward chaining is one of method in an expert system technology to identify with a search of existing symptoms. By doing this modeling, produced a model to identify the level of addiction to games based on six type of game addiction behavior such as Salience, Euphoria, Conflict, Tolerance, Withdrawal, Relapse and Reinstatement. This model can be used as a basis for the development of applications and computer system used to assess the level of game addiction.

Keywords: model, addiction, game, backward chaining.

\section{PENDAHULUAN}

Game merupakan kegiatan menyenangkan yang dilakukan seseorang untuk menghilangkan kepenatan. Sebuah Game memiliki aturan tertentu sehingga pada akhirnya nanti akan diperoleh menang atau kalah. Selain itu, game membawa arti sebuah kontes, fisik atau mental, menurut aturan tertentu, untuk hiburan, rekreasi, atau untuk menang taruhan. Menurut Eddy Liem, Direktur Indonesia Gamer yang merupakan sebuah pencinta games di Indonesia, game online adalah sebuah game atau permainan yang dimainkan secara online via internet, bisa menggunakan PC(personal computer) atau konsul game biasa seperti PS2 ,X-Box dan sejenisnya. Kecanduan game sering juga disebut adiksi game.

Terdapat enam jenis perilaku kecanduan game antara lain Salience, Euphoria, Conflict, Tolerance, Withdrawal, Relapse and Reinstatement. Seseorang dikatakan kecanduan game apabila memenuhi minimal tiga dari enam jenis yang diungkapkan oleh Brown [1]. Menurut penelitian Latubessy, A dan Ahsin, M.N, tingkat keseringan bermain game sangat berpengaruh pada keaktifan anak dalam proses pembelajaran. Sehingga penting sekali mendeteksi tingkat kecanduan terhadap game [2].

Saat ini untuk mendeteksi jenis perilaku kecanduan game belum dapat dilakukan dengan sistem komputer. Jenis perilaku kecanduan game selama ini masih diidentifikasi dengan meilhat gejala-gejala yang ada secara 
manual. Hal tersebut masih memungkinkan terjadi kesalahan dalam proses identifikasi akibat human error. Penilaian setiap orangpun berbeda-beda.

Oleh sebab itu, penelitian ini membuat sebuah model identifikasi jenis perilaku kecanduan game yang dapat dijadikan sebagai standar, menggunakan jenis perilaku kecanduan game yaitu Salience, Euphoria, Conflict, Tolerance, Withdrawal, Relapse and Reinstatement. Metode backward chaining digunakan untuk memodelkan jenis perilaku kecanduan game sehingga menghasilkan seseorang kecanduan game atau tidak.

Menurut T.Sutojo dkk, backward chaining adalah metode yang inferensi yang bekerja mundur kearah kondisi awal. Proses diawali dari goal (yang berada dibagian THEN dari rule IF-THEN), kemudian pencari mulai dijalankan untuk mencocokkan apakah fakta-fakta yang ada cocok dengan premis-premis dibagian $I F$. Jika cocok, rule dieksekusi, kemudian hipotesis dibagian THEN ditempatkan di basis data sebagai fakta baru. Jika tidak cocok, simpan premis dibagian $I F$ kedalam stack sebagai SubGoal. Proses berakhir jika goal ditemukan atau tidak ada rule yang bisa membuktikan kebenaran dari SubGoal atau Goal [3].

Beberapa penelitian terdahulu dibidang sistem pakar antara lain, pada penelitian Sianturi, E., dalam penelitiannya yang berjudul Sistem Pakar Diagnosa Gejala Kecanduan Game Online Dengan Menggunakan Metode Certainty Factor. Penelitian tersebut membagi jenis kecanduan atas tiga kategori yaitu kecanduan ringan, kecanduan sedang dan kecanduan berat. [4]

Kasus yang berbeda didalam penggunaan backward chaining seperti yang dilakukan pada penelitian Iriani, S, dalam jurnalnya yang berjudul Penerapan Metode Backward Chaining pada Sistem Pakar Diagnosa Penyakit Tulang Manusia. Penelitian ini menggunakan model inferensi backward chaining dan teknik pencarian depth first search untuk menghasilkan diagnosa, penyebab, pengobatan dan pencegahan penyakit tulang [5].

\section{METODOLOGI PENELITIAN}

Penelitian ini menggunakan metode pengembangan sistem pakar. Dimana terdapat empat tahap antara lain Identifikasi, Konseptualisasi, Formalisasi, dan Implementasi. Pada penelitian ini hanya menggunakan tiga tahap sampai pada tahap formalisasi. Karena output dari penelitian yang dilakukan dibatasi pada tahap model.

a. Identifikasi

Pada tahap identifikasi dilakukan analisa terhadap masalah yang berhubungan dengan kecanduan game. Langkah awal adalah pencarian fakta akan adanya pengaruh antara kecanduan game dengan perkembangan pembelajaran anak. Kemudian dikumpulkan data dan fakta yang meliputi jenis perilaku kecanduan game. Serta melakukan identifikasi juga terhadap syarat dan ketentuan seseorang dikatakan kecanduan game.

b. Konseptualisasi

Hasil identifikasi masalah di langkah pertama dikaji lebih lanjut dalam tahap konseptualisasi. Pada tahap ini ditemukan relasi antar data hasil identifikasi. Data berbicara bahwa adanya hubungan korelasi negatif antara keseringan bermain game terhadap pembelajaran anak[3]. Sehingga langkah selanjutnya adalah menyusun relasi antar data, yaitu data enam jenis perilaku kecanduan game dan gejala-gejala tiap jenisnya. Tahap ini juga disebar kuisioner kepada beberapa anak guna melihat kecenderungan anak tersebut memiliki enam jenis perilaku kecanduan game atau tidak.

c. Formalisasi

Pada tahap ini dilakukan pemodelan terhadap enam jenis perilaku kecanduan game menggunakan model backward chaining. Dihasilkan beberapa rule atau aturan yang sesuai untuk masalah ini.

Gambar 1 menunjukan alur input yang diperlukan, proses yang dikerjakan, serta output yang dihasilkan dari penelitian yang dikerjakan. Berdasarkan Gambar 1 terlihat jelas data apa saja yang dibutuhkan dalam penelitian diantaranya, data jenis perilaku kecanduan game, data gejala - gejala kecanduan game, dan data anak. Data - data tersebut diolah dengan model backward chaining menggunakan enam dimensi jenis perilaku kecanduan game dan menghasilkan tujuh buah rule yang digunakan untuk menghasilkan model identifikasi kecanduan game. 


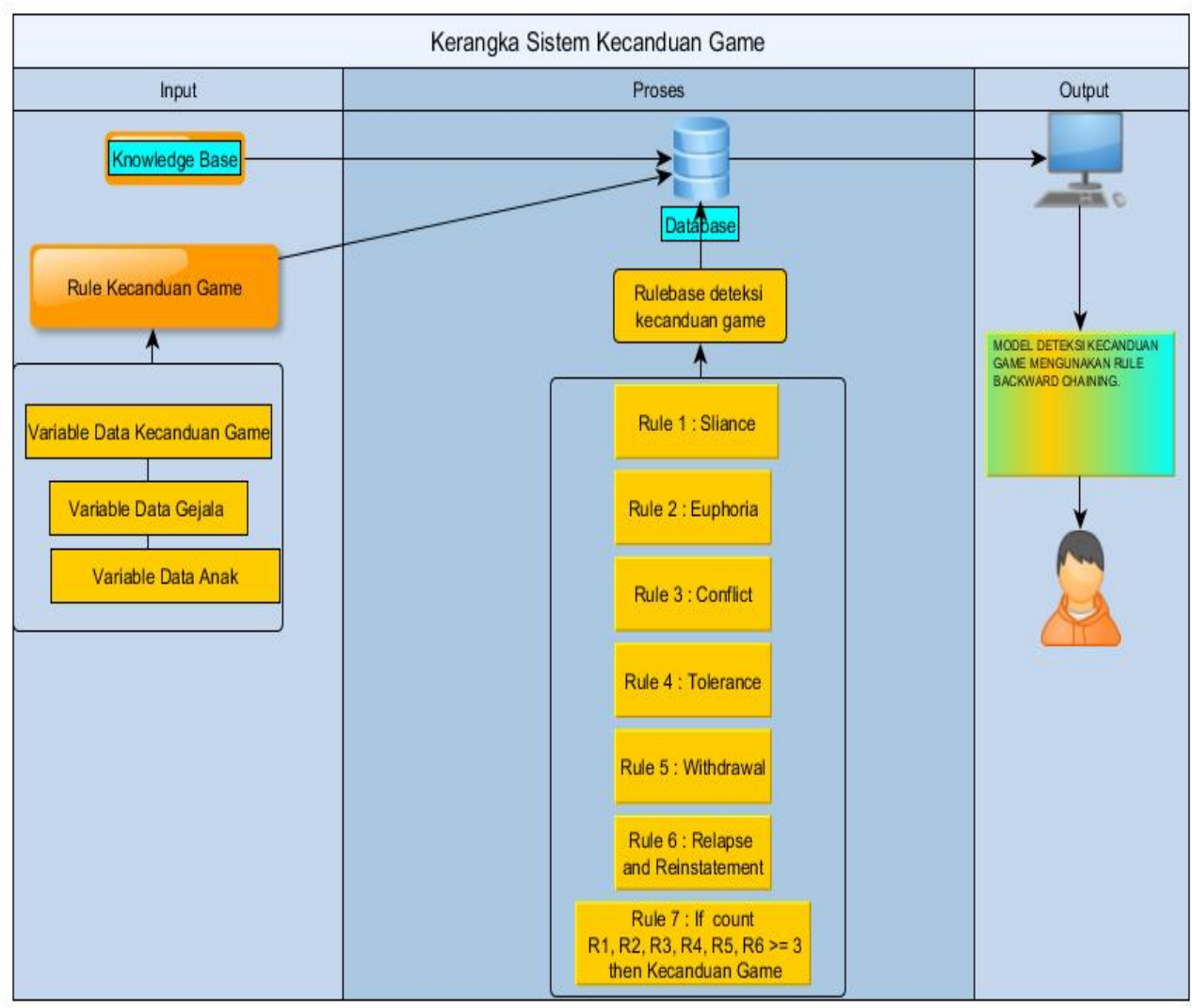

Gambar 1. Alur input proses output dari model jenis perilaku kecanduan game

\section{HASIL DAN PEMBAHASAN}

Jenis perilaku kecanduan game terdiri atas enam yaitu Salience, Euphoria, Conflict, Tolerance, Withdrawal, Relapse and Reinstatement. Untuk memudahkan dalam pemodelan maka, dibuatkan kode_jenis. Kode_jenis digunakan sebagai kode yang unik dan dapat dijadikan primary key untuk jenis perilaku kecanduan game. Dipilih JPKG1 sampai dengan JPKG6 sebagai kode_jenis. Tabel 1 menunjukan enam jenis perilaku kecanduan game dengan kodenya masing-masing. Sementara Tabel 2 menunjukan gejala kecanduan game. Terdapat 12 gejala kecanduan game yang digunakan, yang dianggap mewakili tiap jenis perilaku kecanduan game.

Tabel 1. Jenis perilaku kecanduan game

\begin{tabular}{cc}
\hline Kode_Jenis & Jenis Perilaku Kecanduan Game \\
\hline JPKG1 & Salience \\
JPKG2 & Euphoria \\
JPKG3 & Conflict \\
JPKG4 & Tolerance \\
JPKG5 & Withdrawal \\
JPKG6 & Relapse and Reinstatement \\
\hline
\end{tabular}




\section{Tabel 2. Gejala kecanduan game}

\begin{tabular}{|c|c|c|}
\hline Kode_Gejala & Kode_Jenis & Gejala Kecanduan Game \\
\hline G1 & JPKG1 & $\begin{array}{l}\text { Ketika anda bermain game anda tidak memperdulikan siapapun bahkan } \\
\text { untuk kebutuhan diri sendiri, misalnya makan. }\end{array}$ \\
\hline G2 & JPKG2 & $\begin{array}{l}\text { Permainan internet membuat anda terhibur karena pusing dengan tugas- } \\
\text { tugas sekolah }\end{array}$ \\
\hline G3 & JPKG2 & Anda senang apabila memenangkan permainan \\
\hline G4 & JPKG2 & Anda merasa senang apabila menemukan permainan internet yang baru \\
\hline G5 & JPKG2 & Anda selalu tersenyum dan tertawa saat bermain permainan internet \\
\hline G6 & JPKG3 & Anda jarang membantu orang tua di rumah karena sibuk dengan game \\
\hline G7 & JPKG3 & $\begin{array}{l}\text { Anda sering menolak dan membantah apabila disuruh orang tua yang } \\
\text { sedang membutuhkan bantuan sehingga membuat orang tua marah }\end{array}$ \\
\hline G8 & JPKG3 & Orang tua memenuhi akan kebutuhan anda agar anda tidak marah \\
\hline G9 & JPKG4 & $\begin{array}{l}\text { Ketika anda bermain game, anda selalu meningkatkan level permainan } \\
\text { selama kurang lebih 5-10 menit }\end{array}$ \\
\hline G10 & JPKG4 & Anda menambah keseringan/intensitas waktu bermain anda \\
\hline G11 & JPKG5 & Anda mengaku merasa gelisah apabila sehari tidak bermain game \\
\hline G12 & JPKG6 & $\begin{array}{l}\text { Anda yang pada awalnya bermain permainan selama } 1 \text { jam } \\
\text { permainan, namun semakin lama semakin bertambah pula intensitas } \\
\text { waktu anda untuk bermain game }\end{array}$ \\
\hline
\end{tabular}

Giarratano dan Rilley, menyatakan bahwa Backward chaining merupakan salah satu model penalaran atau penelusuran dalam sistem pakar, dimana penalaran dimulai dengan tujuan kemudian merunut balik ke jalur yang akan mengarahkan ke tujuan tersebut[6]. Berdasarkan data yang ditunjukan pada Tabel 1 dan Tabel 2, maka rule model menghasilkan tujuh rule. Dimulai dari R1 sampai dengan R7, menggunakan pemodelan backward chaining dengan aturan-aturan sebagai berikut.

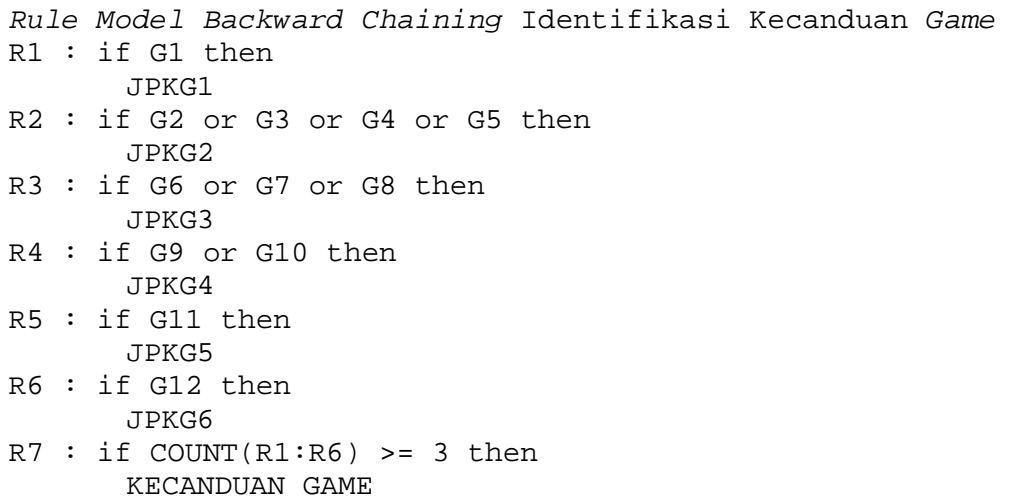

Model tersebut Menggunakan logika or dimana jika pada tiap rule salah satu gejala saja sudah dipenuhi maka konklusi pada rule tersebut benar. Selain ditulis dalam bentuk diatas, model kecanduan game juga dapat juga digambarkan kedalam flowchart seperti yang ditunjukan pada Gambar 2. 


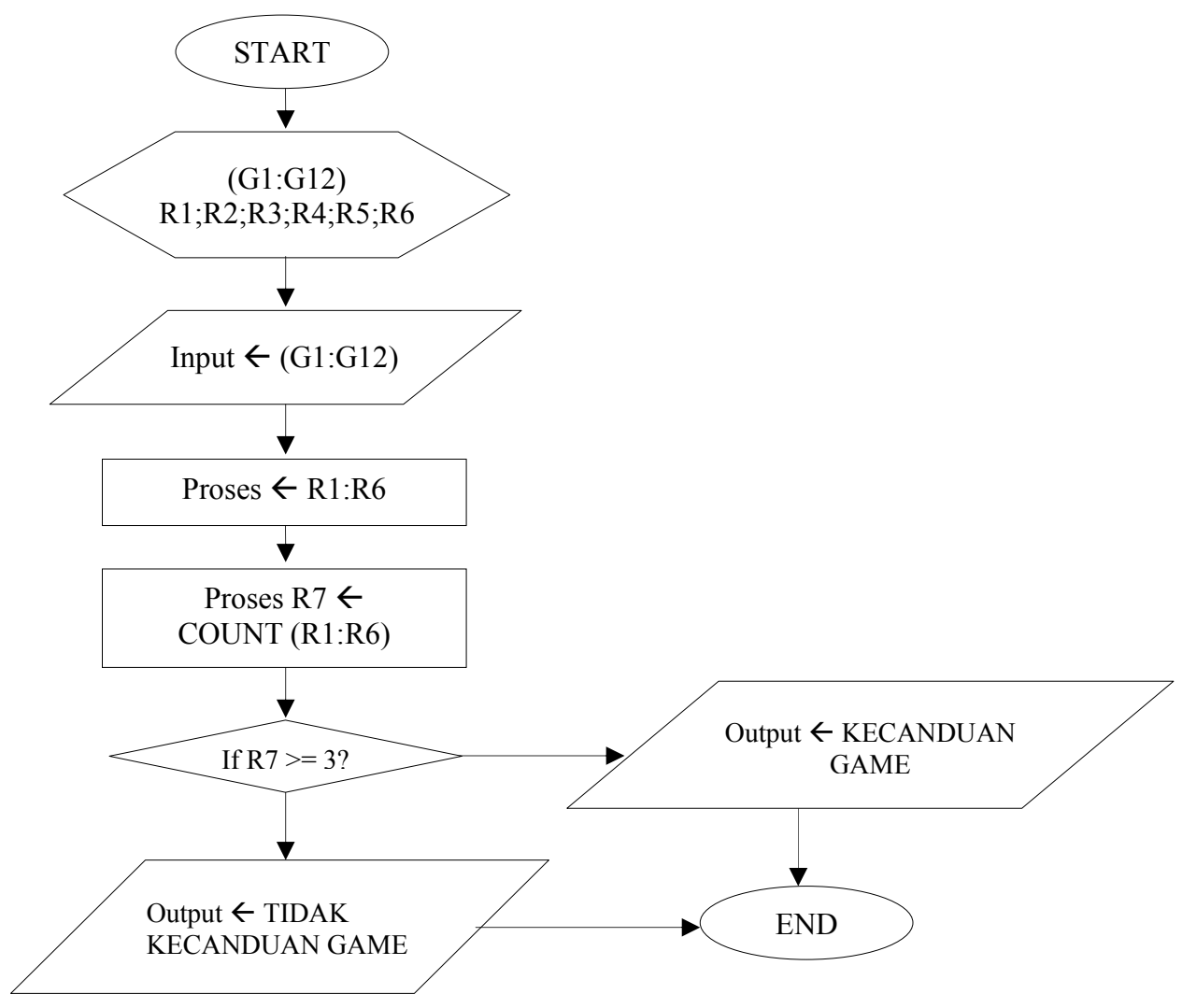

\section{Gambar 2. Flowchart Model Identifikasi Kecanduan Game}

\section{KESIMPULAN}

Beberapa kesimpulan yang diperoleh dari penelitian ini adalah sebagai berikut :

1. Backward chaining dapat dijadikan model dalam identifikasi kecanduan game menggunakan operasi logika or.

2. Penelitian ini menghasilkan tujuh rule dalam memodelkan proses identifikasi kecanduan game menggunakan model penelusuran backward chaining.

3. Penelitian ini menggunakan enam jenis perilaku kecanduan game, yaitu Salience, Euphoria, Conflict, Tolerance, Withdrawal, Relapse and Reinstatement dan dua belas gejala kecanduan game. Namun, gejalagejala tersebut masih dapat diperluas dan disesuaikan dengan jenis perilaku kecanduan game yang ada.

\section{UCAPAN TERIMA KASIH}

Terima kasih kami ucapkan kepada :

1. Lembaga Penelitian(Lemlit) Universitas Muria Kudus,

2. Pusat Pengembangan Anak (PPA) Anugerah GKMI Kudus,

3. Fakultas Teknik Universitas Muria Kudus.

Terima kasih atas segala kerjasama serta dukungan baik berupa dana, data dan doa yang telah diberikan sehingga penulis dapat menyelesaikan artikel ini dengan baik.

\section{DAFTAR PUSTAKA}

[1] Faried. 2012. "Perilaku Remaja Pecandu Game Online”. Skripsi, IKIP PGRI, Semarang.

[2] Latubessy, A., dan Ahsin, M.N. 2016. "Hubungan Antara Adiksi Game Terhadap Keaktifan Pembelajaran Anak Usia 9-11 Tahun”, Jurnal Simetris, 7. 2, 687-692.

[3] Sutojo, T. dkk. (2011). Kecerdasaan Buatan, Andi, Yogyakarta. 
Jurnal SIMETRIS, Vol 8 No 1 April 2017

ISSN: 2252-4983

[4] Sianturi, E. 2014. "Sistem Pakar Diagnosa Gejala Kecanduan Game Online Dengan Menggunaka Metode Certainty Factor", Jurnal Pelita Informatika Budi Darma, VII.3.

[5] Iriani S. 2015. "Penerapan Metode Backward Chaining pada Sistem Pakar Diagnosa Penyakit

[6] Tulang Manusia", IJNS - Indonesian Journal on Networking and Security, 4.1.

[7] Giarratano, J., and Riley, G. (1994). Expert System Principles and Programming, PWS Publishing Company, Boston. 